\title{
Serum biochemistry parameters in the Omani racing Arabian camels (Camelus dromedarius)
}

\author{
Yasmin Elhag Eltahir ${ }^{*}$, Hassan Mohammed $\mathrm{Ali}^{2}$, B.E. Hago ${ }^{2}$ and O. Mahgoub ${ }^{1}$
}

$$
\text { خصائص كيمياء الدم في إبل السباق وحيدة السنام في سلطنة عمان }
$$

ABSTRACT. Blood samples were collected from thirty, 2-year old female Arabian camels from the eastern region of Oman. Camels were managed in the traditional way in the Arabian Gulf region, primarily fed fresh alfalfa and barley grain. Blood was drawn into serum vaccutainers from jugular venipuncture. Serum samples were analyzed by spectrophotometric analysis using a CX7/CX7 serum chemistry analyzer (Synchron, Beckman). Means, standard deviations and minimum and maximum values were calculated using Excel spreadsheets on Microsoft Office 2007. The SAS (2000) package was used to produce coefficient of determination (R2) between the eight serum mineral values. The following mean values \pm standard deviation were recorded: glucose: $92.8 \pm 19.2 \mathrm{mg} / \mathrm{dL}$; total protein (TP): $6.17 \pm$ $0.34 \mathrm{~g} / \mathrm{dL}$; albumin: $32.21 \pm 9.933 \mathrm{mg} / \mathrm{dL}$; blood urea nitrogen $(\mathrm{BUN}): 15.48 \pm 4.49 \mathrm{mg} / \mathrm{dL}$; creatinine: $1.64 \pm 0.238$ $\mathrm{mg} / \mathrm{dL}$; uric acid: $0.28 \pm 0.041 \mathrm{mg} / \mathrm{dL}$; total globulins (TG): $0.28 \pm 0.041 \mathrm{mg} / \mathrm{dL}$; cholesterol: $40.52 \pm 13.225 \mathrm{mg} / \mathrm{dL}$; total bilirubin: $0.34 \pm 0.124 \mathrm{mg} / \mathrm{dL}$; alkaline phosphatase (ALP): $113.9 \pm 29.75$ (IU/L); aspartate aminotransferase (AST): 88.8 \pm 70.03 (IU/L); alanine aminotransferase (ALT): 13.3 \pm 5.97 (IU/L); Gamma-Glutamyl Transpeptidase (GGT): $21.3 \pm 10.18$ (IU/L); lactate dehydrogenase (LD); $419.9 \pm 160.38$ (IU/L); Creatine kinase (CK): $46.3 \pm 16.2$ (IU/L); sodium (Na): $144.5 \pm 5.80 \mathrm{mmol} / \mathrm{L}$; potassium $(\mathrm{K}): 4.23 \pm 0.42 \mathrm{mmol} / \mathrm{L}$; calcium $(\mathrm{Ca}): 9.63 \pm 0.43$; phosphorus $(\mathrm{P}): 9.56 ? \pm 0.76$ $\mathrm{mg} / \mathrm{dL}$; iron $(\mathrm{Fe}): 107.8 \pm 25.54 \mu \mathrm{g} / \mathrm{dl}$; copper $(\mathrm{Cu}): 72.5 \pm 8.08 \mu \mathrm{g} / \mathrm{dl}$; chlorine $(\mathrm{Cl}): 113.0 \pm 4.52 \mathrm{mmol} / \mathrm{L}$. Findings of the current study provide baseline values that may be used by clinicians for racing camels in Oman. There were some significant correlations especially between macro minerals $(\mathrm{Na}, \mathrm{Ca}, \mathrm{K}$, and $\mathrm{P}$ ) that may be used to estimate their values with less cost by reducing the number of elements to be analyzed.

KEYwORDS: Omani Camels; blood profile; serum minerals; trace elements.

المستخلص: تم جمع عينات دم من ك ب ناقة عربية عمرها حوالي سنتين من المنطقة الشرقية من سلطنة عمان. تمت تربية هذه الإبل على الطريقة

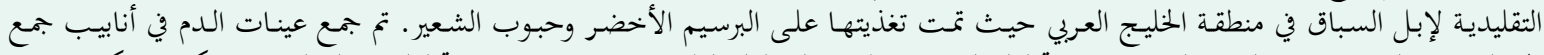

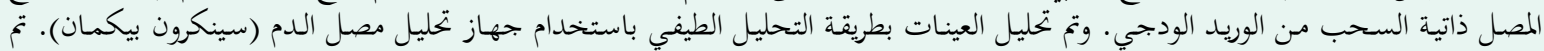

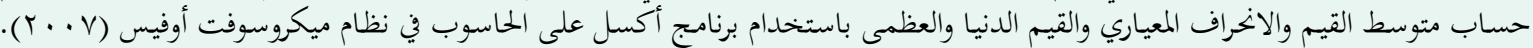

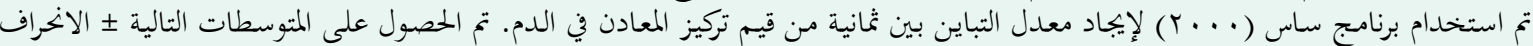

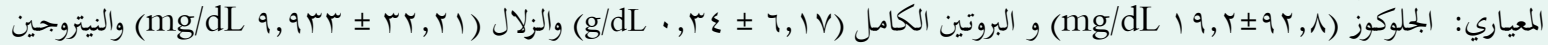

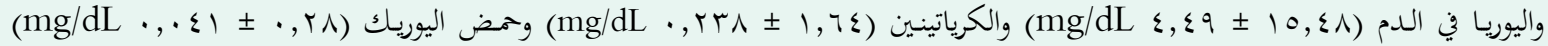

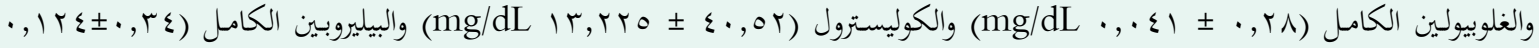

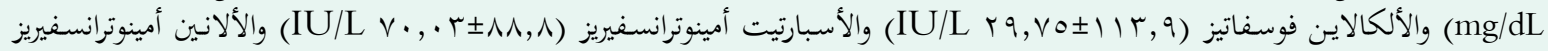

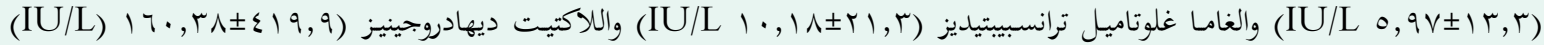

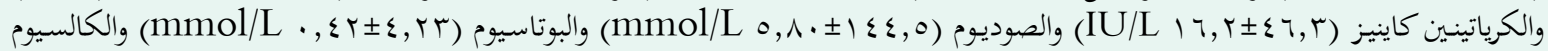

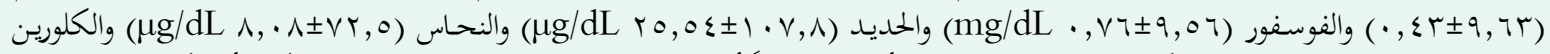

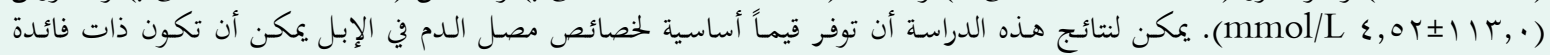

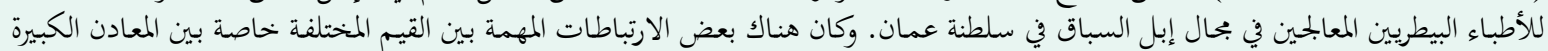

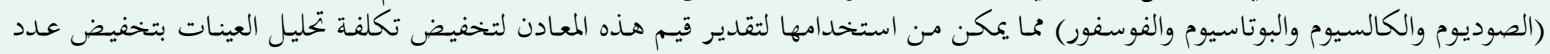

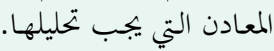
الكلمات المفتاحية: الإبل العمانية ، خصائص الدم ، معادن مصل الدم ، العناصر الدقيفة

\footnotetext{
${ }^{* 1}$ Yasmin Eltahir ( Sultan Qaboos University, College of Agricultural and Marine Sciences, Dpt. of Animal and Veterinary Sciences. Box 34, Al-Khod 123. Sultanate of Oman. email: yasmin@squ.edu.om.

2 Al-Adhid Veterinary \& Agricultural Services, PO Box 110, Al-Qabil 419, Sultanate of Oman

${ }^{3}$ Camel Breeding Center, Directorate of Veterinary Services, Royal Diwan Affairs, PO Box 34, Al-Khod 123, Sultanate of Oman
}

\section{Introduction}

7 he dromedary camel (Camelus dromedarius) is of great importance to nomadic and rural communities mainly in the arid regions of Africa, the Middle East and the Indian sub-continent. It provides high quality animal protein in the form of milk and meat and as a mean of transportation and work. Over the past few decades the camel has gained popularity and importance as a racing animal in the Arabian Gulf region. The camel is well suited to harsh environments character- 
ized by scarcity of water and vegetation as well as high ambient temperatures and rough terrain. This is because of its unique anatomical and physiological adaptations to such environments.

There are about 250,000 camels in the Sultanate of Oman (FAOSTAT, 2014) with the highest population in the southern part of the country (Dhofar) followed by the Al-Sharqiyah (Eastern) and Dhahirah regions (OMAF, 2012). Camels in the eastern region of Oman are mainly kept for racing. Good racing camels can be worth hundreds of thousands of dollars in the Arabian Gulf camel markets and great care is taken in raising and training these camels the traditional way. This includes a diet of green alfalfa, barley grain and sometimes honey, gee, milk and even eggs.

Biochemical values are useful for evaluating health status in animals including camels although in the latter species, some traits such as minerals homeostasis is very efficient and lead to a relatively constant levels irrespective of intake. However, published information on these parameters in camel shows a wide range of values which could be attributed to differences in breed, age, sex and sampling or analytical methods (Mohamed and Hussein, 1999). The metabolic profile of camels is affected by season, mineral supplementation and health status (Faye et al., 1995). Due to variations in haematological and biochemical parameters resulting from variations in these factors each laboratory is advised to establish what should be considered normal values for racing camels in their own region (Mohamed and Hussein, 1999). Serum mineral levels are also affected by degree of hydration which is variable in camels raised under traditional range grazing systems (Ayoub and Saleh, 1998). However, this may not apply to racing camels as they are typically well looked after and not deprived of water or feed.

Macro and micro minerals are essential elements for animal functioning and health. Trace elements such as $\mathrm{Co}, \mathrm{Se}, \mathrm{Cu}, \mathrm{Zn}$ and $\mathrm{Fe}$ are integral components of some enzymes and other important constituents of biologically active compounds. There are some published reports on biochemical values in camels. These include animal blood serum mineral values from Sudan (Abu Damir et al., 2008; Ahmed et al., 2003; Mohamed, 2004), Saudi Arabia (Al-Busadah, 2007; Al-Shami, 2009; Osman and Al-Busadah, 2003; ), Kuwait (Mohamed and Hussein, 1999), United Arab Emirates (Faye et al., 2008; Wernery et al., 1999), Iran (Badiei et al., 2006; Mohri et al, 2008), Pakistan (Zia-ur-Rahman et al, 2007), Nigeria (Mohammed et al., 2007), Kenya (Kuria et al., 2006) and even Europe (Faye et al., 1995). There are also some reports on the serum mineral values in the Bactrian camel (Wernery et al., 1999; Zongping, 2003).

Camel racing is a demanding process with animals being kept on strict diet and strenuous exercise prior to races and running for up to $10 \mathrm{~km}$ distances in some races. Certain post-race haematological and biochemical changes occur but return to pre-racing levels after a period of rest (Mohamed and Hussein, 1999).

There is a however, scarcity of information on Omani camel serum biochemical profile. El Tahir et al. (2010) reported some serum mineral values of Omani female racing camels. Therefore, this investigation has been carried out to provide basic reference levels of selected serum biochemistry parameters for clinicians and researchers working with the dromedary camels in the Sultanate of Oman.

\section{Materials and methods}

\section{Animals and sampling}

Blood samples were collected from thirty female, 2-year Omani Arabian camels (Camelus dromedarius). The age of the animals was determined by asking owners and examining the dentition. The camels were raised in Al-Sharqiyah (Eastern) region of Oman around Al-Mudhaibi in the style adopted by most racing camel owners in the Gulf region. They were fed approximately three kilograms of alfalfa plus one kilogram of soaked barley in the morning and three kilograms of alfalfa plus 2 kilograms of soaked barley in the evening (as fed). They were offered approximately 20 liters of water daily. All animals were tested for trypanosomiasis using buffy coat test and internal parasites using faecal egg counts.

\section{Serum analytical methodology}

Eight milliliter blood samples were drawn into plain vaccutainers tubes from jugular venipuncture. Samples were centrifuged at $300 \mathrm{rpm}$ for $5 \mathrm{~min}$ to separate the serum which was subsequently transported in a cool box to the laboratory at Sultan Qaboos University where they were stored at $-20^{\circ} \mathrm{C}$ until analysis.

Serum samples were analyzed in the Camel Breeding Unit of the Diwan Royal Affairs, Sultanate of Oman for glucose; total protein (TP), albumin, blood urea nitrogen (BUN), creatinine, uric acid, total globulins (TG), cholesterol, total bilirubin, alkaline phosphatase (ALP), aspartate aminotransferase (AST), alanine aminotransferase (ALT), gamma-glutamyl transpeptidase (GGT), lactate dehydrogenase (LD), creatine kinase (CK), sodium $(\mathrm{Na})$, potassium $(\mathrm{K})$, calcium $(\mathrm{Ca})$, phosphorus $(\mathrm{P})$, iron $(\mathrm{Fe})$, copper $(\mathrm{Cu})$ and chlorine $(\mathrm{Cl})$. All analyses were carried out by spectrophotometric analysis using a CX7/CX7 serum chemistry analyzer (Synchron, Beckman).

\section{Statistical analyses}

Means, standard deviations and minimum and maximum values were calculated using Excel spreadsheets on Microsoft Office 2007. The SAS (2000) package was used to produce Pearson coefficient of correlations (R) between the eight serum mineral values. Excel spreadsheets on Microsoft Office 2007 were used to calculate regression lines between $\mathrm{Na}$ and other macrominerals ( 
polynomial)

\section{Results and discussion}

\section{General health}

General health of experimental animals appeared to be excellent by the standards of racing camels in the Gulf region. They were well groomed and well looked after. Racing camel owners in the Arabian Gulf region are known to care for the health and body condition of their animals. All animals tested negative for trypanosomiasis (buffy coat test). Trypanosomiasis (Surra disease) is widely spread among camels in the region and usually has a negative impact on their performance and blood profile. For instance Ahmadi-hamedani et al. (2014) reported that serum analyses of camels heavily infected with Trypanosoma evansi indicated anemia, leukocytosis, hyperproteinemia, hypoalbuminemia, hyperglobulinemia, reduction $\mathrm{A} / \mathrm{G}$ ratio, increased $\alpha 1$ and $\beta$ globulins and decreased $\alpha 2$ globulins and increased concentration of gamma-glutamyl transferase enzyme compared to non-infected camels. Faecal sample analyses (egg counts) showed no significant internal parasites infestation. The animals had been dewormed by Albendazole $2500 \mathrm{mg} / \mathrm{animal}$ by owners.

\section{Serum chemistry profiles}

Several serum profiles had been measured in experimental animals and are grouped as: glucose, protein (albumin, total globulin and total protein), BUN, kidney function parameters (creatinine and uric acid), cholesterol, total bilirubin, liver enzymes (ALP, AST, GGT, LD, and $\mathrm{CK}$ ), $\mathrm{Co} 2$, and minerals ( $\mathrm{Na}, \mathrm{Ca}, \mathrm{K}, \mathrm{Po} 4, \mathrm{Fe}, \mathrm{Cu}, \mathrm{Cl}$,). Range, mean and standard deviation values are presented in Table 1. Correlation within these groups was studied (Tables 2-4). The standard deviation indicates the degree of variation in these parameters. Wide variations in metabolic parameters exist in published literature and were mainly attributed to variability in nutritional regimes, mineral supplementation, season and presence of disease (Faye et al., 1995). These authors distributed camels to four groups as follows: (1) class with low protein, high minerals and high GGT; (2) class with low $\mathrm{Cu}$

Table 1. Means, standard deviations, maximum and minimum values of serum biochemistry parameters in female Omani racing camels; $\mathrm{n}$ is the number of observations used for each parameter .

\begin{tabular}{|c|c|c|c|c|c|}
\hline Parameter & $\mathbf{n}$ & Mean & $(\mathrm{SD})$ & Min. & Max. \\
\hline Glucose (mg/dL) & 29 & 92.8 & 19.23 & 56.0 & 158.0 \\
\hline Albumin (g/dL) & 28 & 2.8 & 0.17 & 2.50 & 3.10 \\
\hline TG (mg/dL) & 29 & 32.2 & 9.93 & 11.0 & 66.0 \\
\hline Total protein $(\mathrm{g} / \mathrm{dL})$ & 29 & 6.2 & 0.34 & 5.5 & 6.8 \\
\hline Uric acid (mg/dL) & 29 & 0.3 & 0.04 & 0.2 & 0.3 \\
\hline Creatinine (mg/dL) & 27 & 1.6 & 0.24 & 1.3 & 2.2 \\
\hline BUN (mg/dL) & 27 & 15.5 & 4.49 & 8.0 & 26.0 \\
\hline Cholesterol (mg/dL) & 29 & 40.5 & 13.23 & 4.0 & 77.0 \\
\hline Total bilirubin (mg/dL) & 29 & 0.3 & 0.12 & 0.1 & 0.6 \\
\hline \multicolumn{6}{|l|}{ Enzymes } \\
\hline ALP (IU/L) & 29 & 113.9 & 29.75 & 50.0 & 187.0 \\
\hline AST (IU/L) & 29 & 88.8 & 70.03 & 57.0 & 374.0 \\
\hline ALT (IU/L) & 29 & 13.3 & 5.97 & 9.0 & 37.0 \\
\hline GGT (IU/L) & 29 & 21.3 & 10.181 & 13.0 & 64.0 \\
\hline $\mathrm{LD}(\mathrm{IU} / \mathrm{L})$ & 28 & 419.9 & 160.38 & 303.0 & 971.0 \\
\hline CK (IU/L) & 29 & 46.3 & 16.18 & 29.0 & 107.0 \\
\hline \multicolumn{6}{|l|}{ Minerals } \\
\hline $\mathrm{Fe}(\mu \mathrm{g} / \mathrm{dl})$ & 29 & 107.8 & 25.54 & 56.0 & 158.0 \\
\hline $\mathrm{Cu}(\mu \mathrm{g} / \mathrm{dl})$ & 29 & 72.5 & 8.08 & 54.0 & 89.0 \\
\hline $\mathrm{Ca}(\mathrm{mg} / \mathrm{dl})$ & 29 & 9.6 & 0.48 & 8.70 & 10.3 \\
\hline Po4 (mg/dl) & 29 & 9.6 & 0.76 & 5.0 & 8.5 \\
\hline $\mathrm{K}(\mathrm{mmol} / \mathrm{l})$ & 29 & 4.2 & 0.42 & 6.5 & 5.0 \\
\hline $\mathrm{Cl}(\mathrm{mmol} / \mathrm{l})$ & 29 & 113.1 & 4.52 & 105.4 & 127.2 \\
\hline $\mathrm{Na}(\mathrm{mmol} / \mathrm{l})$ & 29 & 144.5 & 5.80 & 132.3 & 160.5 \\
\hline $\mathrm{Na} / \mathrm{K}$ & 29 & 28.1 & 2.86 & 21.2 & 33.9 \\
\hline $\mathrm{CO}_{2}(\mathrm{mmol} / \mathrm{l})$ & 29 & 18.3 & 1.65 & 13.9 & 22.3 \\
\hline
\end{tabular}


and cerulplasmin; (3) class with high mineral values and protein indicators; and (4) class with intermediate values.

\section{Glucose}

The blood glucose level or concentration is the amount of glucose in the animal's blood which is the primary source of energy for the body's cells besides blood lipids. The animal's body naturally tightly regulates blood glucose levels as a part of metabolic homeostasis. Glucose is transported from the intestines or liver to body cells via the bloodstream, and is made available for cell absorption via the hormone insulin. Monitoring blood glucose levels is very essential to determine animal health particularly in racing camels which have a strict diet regime and usually go through rigorous training and competition.

The glucose levels in Omani camel serum ranged between 56 and $158 \mathrm{mg} \cdot \mathrm{dL}^{-1}$ with a mean of $92.8 \pm 19.23$ $\mathrm{mg} \cdot \mathrm{dL}^{-1}$ (Table 1). This is an equivalent of $5.14 \mathrm{mmol}$. These levels are within the range reported for normal values in 2-12 year old Arabian camels (76-129 mg.dL $\mathrm{dL}^{-1}$ ) by Wernery et al. (1999) and indoor (130.2 $\left.\mathrm{mg} \cdot \mathrm{dL}^{-1}\right)$ and free grazing (105 mg.dL ${ }^{-1}$ ) Saudi camels (Al-Sha$\mathrm{mi}, 2009$ ). That was also well within the range reported for camels of various ages and breeds (Yadav and Bissa, 1998). The latter authors observed that blood glucose levels varied widely over a range of $27.6-214.4 \mathrm{mg} \cdot \mathrm{dL}^{-1}$. Glucose levels in camel blood are reported to be generally higher than in those of ruminants (Bhatia, 1986).

Blood glucose levels in camels are affected by a variety of factors. Glucose levels in camels are strongly affected by age with levels decreasing with advanced age (Roussel et al., 1982; Elias and Yagil, 1984) and by season (Mehrotra and Gupta, 1989) with wet season samples having higher glucose levels than dry season ones (Mohammed et al., 2007). Indoor raised camels had higher serum glucose levels than free grazing camels (Al-Sha$\mathrm{mi}, 2009)$. This is mainly attributed to the better level of nutrition in the former group, which was fed a concentrate diet plus hay. Glucose levels were much higher in
Saudi camels $\left(134.4 \mathrm{mg} \cdot \mathrm{dL}^{-1}\right)$ than cattle $\left(49.0 \mathrm{mg} \cdot \mathrm{dL}^{-1}\right)$ or sheep $\left(65.0 \mathrm{mg} \cdot \mathrm{dL}^{-1}\right)$ raised under similar conditions (Osman and Al-Busadah, 2003).

The levels of glucose in Omani racing camels falls within those of camels reported from different regions of the world indicating that they were healthy and not affected by type of nutrition or rigorous exercise.

\section{Total serum protein}

Serum total protein is made up mainly of albumin and globulin. The total protein test is a faster and cheaper biochemical test for measuring the total amount of protein in serum. Low concentrations below the reference range usually reflect low albumin concentration such as in the cases of liver disease or acute infection whereas high levels are observed in conditions causing an increase in immunoglobulins or during dehydration.

The mean TP in Omani camels (Table 1) was $6.17 \mathrm{mg} \cdot \mathrm{dL}^{-1}$ (range of $5.5-6.8 \pm 0.34 \mathrm{mg} \cdot \mathrm{dL}^{-1}$ which are within range reported for normal values in 2-12 year old Arabian camels $\left(6.0-7.8 \mathrm{mg} \cdot \mathrm{dL}^{-1}\right)$ by Wernery et al. (1999) and the range reported by Yadav and Bissa, (1998) for camels of various sexes, breeds and ages. Faye et al. (1995) reported a range equivalent of 5.13$8.66 \mathrm{mg} \cdot \mathrm{dL}^{-1}$ for female camels raised in France. Mean value of TP in Egyptian camels was $7.60 \pm 0.25 \mathrm{mg} \cdot \mathrm{dL}^{-1}$ (Seleim et al., 2003) and was $5.3-7.5 \mathrm{mg} \cdot \mathrm{dL}^{-1}$ in Nigerian camels (Mohammed et al., 2007). The values are also comparable to those of Saudi camels (range of 4.9$10.2 \mathrm{mg} \cdot \mathrm{dL}^{-1}$ ) reported by Al-Busadah (2007) and Sudanese camels $7.0 \mathrm{mg} \cdot \mathrm{dL}^{-1}$ reported by Omer et al. (2008). However, the value in the current study was lower than that reported for Indian camels of similar age (Yadav and Bissa, 1998).

Yadav and Bissa, (1998) reported that total serum protein content may be influenced by age, sex, pregnancy, rut or disease. TP was higher in serum of male camels during the rutting season than in the non-breeding season (Koudier et al., 1988) and Mohammed et al. (2007) reported that female camels had higher levels than males. Osman and Al-Busadah (2003) reported

Table 2. Coefficients of determination $\left(R^{2}\right)$ and their significance between some serum biochemistry parameters in Omani racing camels.

\begin{tabular}{|c|c|c|c|c|c|c|c|c|}
\hline & BUN & CREA & $\mathrm{TP}$ & ALB & GLU & TG & CHOL & TBIL \\
\hline BUN & 1 & $0.51^{* * *}$ & -0.06 & -0.20 & -0.12 & 0.15 & 0.33 & $-0.46^{*}$ \\
\hline CREA & $0.51^{* * *}$ & 1 & 0.21 & 0.03 & -0.03 & $0.48^{*}$ & 0.27 & -0.08 \\
\hline $\mathrm{TP}$ & -0.06 & 0.21 & 1 & $0.84^{* * * *}$ & $0.40 *$ & 0.029 & 0.34 & $0.40^{*}$ \\
\hline ALB & -0.20 & 0.03 & $0.84 * \%$ & 1 & $0.53^{* * *}$ & -0.23 & $0.38^{*}$ & 0.27 \\
\hline GLU & -0.12 & -0.03 & $0.40^{*}$ & $0.53^{* * *}$ & 1 & $-0.57^{* * *}$ & -0.00 & -0.03 \\
\hline TG & 0.15 & $0.48^{*}$ & 0.03 & -0.23 & $-0.57^{* * *}$ & 1 & 0.02 & 0.14 \\
\hline CHOL & 0.3301 & 0.26953 & 0.33732 & 0.37598 & -0.00055 & 0.01791 & 1 & 723 \\
\hline TBIL & $-0.46^{*}$ & -0.08 & 0.40 & 0.27 & -0.03 & 0.14 & 0.01 & 1 \\
\hline
\end{tabular}

$* p<0.05 ; * * * ; p<0.01 ; * * * ; * 0<0.001$ 
comparable values in Saudi camels $\left(7.1 \mathrm{mg} \cdot \mathrm{dL}^{-1}\right)$ which were lower than in cattle $\left(8.2 \mathrm{mg} \cdot \mathrm{dL}^{-1}\right)$ but comparable to sheep $\left(6.9 \mathrm{mg} \cdot \mathrm{dL}^{-1}\right)$.

Total protein levels recorded in the present study indicate normal levels of healthy and normally hydrated animals.

\section{Albumin}

Blood serum albumin, is the most abundant protein dissolved in animal blood plasma. It is a globular protein produced by the liver and is essential for maintaining the osmotic pressure needed for proper distribution of body fluids between blood vessels and body tissues. Albumin in the urine usually denotes the presence of kidney disease.

The mean value of albumin in Omani racing camels was $2.80 \pm 0.167 \mathrm{mg} \cdot \mathrm{dL}^{-1}$ with a range of $2.5-3.1 \mathrm{mg} \cdot \mathrm{dL}^{-1}$ (Table 1). These are well within range reported for normal values in 2-12 year old Arabian camels (2.8-5.6 mg. $\left.\mathrm{dL}^{-1}\right)$ by Wernery et al. (1999); Nigerian (23-40 g/l, equivalent for 2.3-4.0 mg.dL-1; Mohammed et al., 2007) and Saudi camels which ranged between 3.1-6.2 mg. $\mathrm{dL}^{-1}$ (Al-Busadah, 2007). Comparable level (3.3 mg.dL-1) was reported for Egyptian camels (Seleim et al., 2003) and 22.3-46.3 g/l (equivalent for 2.23-4.63 $\mathrm{mg} \cdot \mathrm{dL}^{-1}$ ) for French female camels (Faye et al., 1995). Similar levels (3.3 $\mathrm{mg} \cdot \mathrm{dL}^{-1}$ ) were reported in Sudanese camels (Omer et al., 2008)

Sarwar et al. (1992) reported that albumin levels in camels are higher than those in ruminant animals. However, Osman and Al-Busadah (2003) reported comparable values in Saudi camels $\left(3.7 \mathrm{mg} \cdot \mathrm{dL}^{-1}\right)$, cattle $\left(4.5 \mathrm{mg} \cdot \mathrm{dL}^{-1}\right)$ and sheep $\left(3.5 \mathrm{mg} \cdot \mathrm{dL}^{-1}\right)$ raised under similar conditions. Sex effects on albumin had been reported with females having higher levels of albumin than males (Mohammed et al., 2007). Therefore, albumin levels in Omani racing camels in the present study indicate normal healthy animals. These values may be used as guiding reference for professionals in the field.

\section{Total globulin (TG)}

Globulins are insoluble proteins in water or highly concentrated salt solutions but soluble in moderately concentrated salt solutions. The plasma globulins can be separated into five fractions by serum protein electrophoresis. These fractions are the alpha1, alpha2, beta1 and beta 2 globulins, and the gamma globulins. The globulins are involved in the inflammatory process, clotting factors, complement components and immunoglobulins.

The mean value of TG in Omani racing camels was $3.22 \pm 0.99 \mathrm{mg} \cdot \mathrm{dL}^{-1}$ with a wide range of 1.10 $6.60 \mathrm{mg} \cdot \mathrm{dL}^{-1}$ (Table 1). TG in Indian camels ranged between 3.163 .56 (Patodkar et al. (2010). TG in Saudi camels of various breeds and sexes (Al-Busadah, 2007) ranged between $\left.1.5-5.4 \mathrm{mg}^{\mathrm{dL}} \mathrm{dL}^{-1}\right)$. Levels of $4.32 \mathrm{~g} / \mathrm{l}$ were reported for Egyptian camels (Seleim et al., 2003) and
21.5-49.9 g/l (2.15-4.99 $\left.\mathrm{mg} \cdot \mathrm{dL}^{-1}\right)$ were reported for French female camels (Faye et al., 1995).

Levels of globulins in Omani racing camels were consistent with those of total proteins and albumins indicating healthy animals. Values may be used as reference for racing camels in Oman.

\section{Blood urea nitrogen (BUN)}

BUN is a test for urea nitrogen in the animal's blood which is formed when protein breaks down. BUN levels higher than normal may indicate excessive protein in the GI tract, dehydration, kidney failure or diseases, shock or urinary tract obstruction. Lower-than-normal levels may indicate: liver failure, low protein diet, malnutrition or over-hydration. Racing camels reared in a very strict way may be exposed to some of these conditions.

The mean BUN in Omani racing camels was 15.48 $\pm 4.49 \mathrm{mg} \cdot \mathrm{dL}^{-1}(5.51 \mathrm{mmol})$ with a wide range of $8-26 \mathrm{mg} \cdot \mathrm{dL}^{-1}$ (Table 1$)$. These figures are comparable to those of $15.4 \pm 4.52 \mathrm{mg} \cdot \mathrm{dL}^{-1}$ reported by Mohamed and Hussein (1999) in Kuwaiti racing camels. Reports on BUN values in the literature vary a lot. The range of normal values in 2-12 year old Arabian camels in UAE was $10-17 \mathrm{mg} \cdot \mathrm{dL}^{-1}$ ) reported by Wernery et al. (1999). A wide range $\left(4.1-69 \mathrm{mg} \cdot \mathrm{dL}^{-1}\right)$ was also reported by Faye et al. (1995) in female camels raised in temperate regions. Yadav and Bissa (1998) reported a range of 11$78 \mathrm{mg} \cdot \mathrm{dL}^{-1}$. Values of $24.9 \mathrm{mg} \cdot \mathrm{dL}^{-1}$ were reported in $\mathrm{Su}-$ danese camels. Levels of $37.0 \mathrm{mg} \cdot \mathrm{dL}^{-1}$ were reported for Egyptian camels (Seleim et al., 2003).

BUN values in Omani female camels in the present study $\left(5.5 \mathrm{mg} \cdot \mathrm{dL}^{-1}\right)$ appear to be within the range reported for BUN levels in the blood of Saudi camels ranged between 3.2-6.2 $\mathrm{mg} \cdot \mathrm{dL}^{-1}$ (Al-Busadah, 2007). The range of BUN in Nigerian camels was $2.4-8.5 \mathrm{mg} \cdot \mathrm{dL}^{-1}$ with females having higher levels than males (Mohammed et al., 2007). Indoor raised camels had higher levels (5.6 $\mathrm{mmol} / \mathrm{L})$ than free grazing ones $(3.1 \mathrm{mmol} / \mathrm{L})$ as a result of better level of nutrition (Al-Shami, 2009). Saudi camels (Osman and Al-Busadah, 2003) had comparable levels of urea to sheep ( $\left.49.8 \mathrm{vs} .52 .6 \mathrm{mg} \cdot \mathrm{dL}^{-1}\right)$, which were much higher than those in cattle $\left(17.2 \mathrm{mg} \cdot \mathrm{dL}^{-1}\right)$.

Values of BUN in Omani racing camels in the current study are in line with normal values of total protein and its component indicating healthy animals. They may be used as clinical reference for the breed.

\section{Creatinine}

Serum creatinine is an important indicator of renal health. It is a byproduct of muscle metabolism that is excreted by the kidneys. Creatine is synthesized primarily in the liver and the kidney then transported through blood to the other organs, muscle, and brain.

The mean value of creatinine in Omani racing camels was $1.6 \pm 0.24 \mathrm{mg} \cdot \mathrm{dL}^{-1}$ with a range of 1.3 $2.2 \mathrm{mg} \cdot \mathrm{dL}^{-1}$ (Table 1 ), which are similar to normal values in 2-12 year old Arabian camels in UAE (1.3-2.2 mg.dL ${ }^{-1}$ ) 
Table 3. Coefficients of determination $\left(R^{2}\right)$ and their significance between some serum biochemistry parameters in Omani racing camels

\begin{tabular}{|c|c|c|c|c|c|c|c|c|}
\hline & ALP & AST & ALT & GGT & LD & CK & $\mathrm{CO}_{2}$ & URIC \\
\hline ALP & 1 & 0.03 & 0.05 & -0.00 & 0.13 & 0.21 & -0.13 & -0.13 \\
\hline AST & 0.03 & 1 & $0.98^{* * *}$ & $0.94^{* * * *}$ & $0.94^{* * * *}$ & 0.11 & 0.07 & 0.16 \\
\hline ALT & 0.05 & $0.98^{* * * *}$ & 1 & $0.91^{* * * *}$ & $0.93^{* * *}$ & 0.12 & 0.15 & 0.08 \\
\hline GGT & -0.00 & $0.94^{* * * *}$ & $0.91^{* * * *}$ & 1 & $0.89^{* * *: k}$ & 0.17 & 0.16 & 0.20 \\
\hline LD & 0.13 & $0.94^{* * * *}$ & $0.93^{* * *}$ & $0.89^{* * * *}$ & 1 & 0.16 & 0.01 & 0.19 \\
\hline CK & 0.21 & 0.11 & 0.12 & 0.17 & 0.16 & 1 & 0.09 & 0.28 \\
\hline $\mathrm{CO} 2$ & -0.13 & 0.07 & 0.15 & 0.16 & 0.01 & 0.09 & 1 & -0.01 \\
\hline URIC & -0.13 & 0.16 & 0.08 & 0.20 & 0.19 & 0.28 & -0.01 & 1 \\
\hline
\end{tabular}

$\because p<0.05 ; * ; p<0.01 ; * ; * ; * 0.001$

reported by Wernery et al. (1999). They are also comparable to those of $1.97 \mathrm{mg} \cdot \mathrm{dL}^{-1}$ reported by Mohamed and Hussein (1999) in Kuwaiti racing camels. Lower levels of $0.93 \mathrm{mg} / \mathrm{dl}$ were reported for Egyptian camels (Seleim et al., 2003).

Creatinine values recorded in the present study are equivalent to $0.15 \mathrm{mmol} / \mathrm{L}$ which appears to be comparable to creatinine levels in serum of Saudi camels with a range of 0.16-0.53 mmol/L (Al-Busadah, 2007) Mohammed et al. (2007) reported a range of 47-118 $\mu \mathrm{mol} / \mathrm{l}$ with levels higher during the wet season.

Osman and Al-Busadah (2003) reported comparable values in Saudi camels $\left(1.5 \mathrm{mg} \cdot \mathrm{dL}^{-1}\right)$ to cattle (1.3 $\mathrm{mg} \cdot \mathrm{dL}^{-1}$ but higher than sheep $\left(1.0 \mathrm{mg} \cdot \mathrm{dL}^{-1}\right)$.

Creatinine values recorded in the current study are in line with values of protein and BUN indicating that Omani racing camels has healthy renal function. They may be used as clinical references for the breed.

\section{Uric acid}

Uric acid (C5H4N4O3) is a heterocyclic compound of carbon, nitrogen, oxygen, and hydrogen that forms ions and salts known as urates and acid urates. It is a product of the metabolic breakdown of purine nucleotides. Uric acid is associated with several medical conditions including gout, diabetes and the formation of kidney stones. Uric acid is reabsorbed by renal tubules in mammals.

The mean value of uric acid in Omani racing camels was $0.28 \pm 0.041 \mathrm{mg} \cdot \mathrm{dL}^{-1}$ with a range of $0.2-0.3 \mathrm{mg} \cdot \mathrm{dL}^{-1}$ (Table 1). Seleim et al. (2003) reported a higher value of $1.68 \mathrm{mg} \cdot \mathrm{dL}^{-1}$ in Egyptian camels. The Uric acid values in the present study $(166.5 \mu \mathrm{mol} / \mathrm{l})$ were comparable to the $160-273 \mu \mathrm{mol} / \mathrm{l}$ reported by Haroun (1994) for Saudi camels and the $217 \mu \mathrm{mol} / \mathrm{l}$ for fasted and fed llamas reported by Bakker et al. (1996). Uric acid values in camel and llama are considerably higher than those typically observed in cattle and sheep (Bakker et al., 1996).

Therefore, low levels of uric acid $\left(0.2-0.3 \mathrm{mg} \cdot \mathrm{dL}^{-1}\right)$ indicate healthy kidney functions in Omani racing camels and may be used as clinical references for the breed.

\section{Cholesterol}

Cholesterol is a modified steroid lipid molecule and is an essential structural component of animal cell membranes. It is required to maintain membrane structural integrity and fluidity. It also serves as a precursor for the biosynthesis of steroid hormones, bile acids, and Vitamin D. The liver cells typically produce greater amounts than other cells.

The mean value of cholesterol in Omani racing camels was $40.52 \pm 13.225 \mathrm{mg} \cdot \mathrm{dL}^{-1}$ with a wide range of 4.0$77.0 \mathrm{mg} \cdot \mathrm{dL}^{-1}$ equivalent of $1.1 \mathrm{mmol} / \mathrm{l}$ (Table 1 ). These figures are comparable to those of $<33 \mathrm{mg} \cdot \mathrm{dL}^{-1}$ reported by Mohamed and Hussein (1999) in Kuwaiti racing camels. Cholesterol levels in blood of Saudi camels ranged between 1.91-4.2 mmol/l (Al-Busadah, 2007). System of management significantly affected cholesterol levels in camel blood. Al-Shami (2009) reported values of 82.1 and $60.5 \mathrm{mg} / \mathrm{L}$ in indoor and free grazing camels. Osman and Al-Busadah (2003) reported values of $58.4 \mathrm{~g} /$ $\mathrm{dL}$ in Saudi camels which were comparable to those in sheep $\left(69.6 \mathrm{mg} \cdot \mathrm{dL}^{-1}\right)$ but significantly less than those in cattle $\left(149.4 \mathrm{mg} \cdot \mathrm{dL}^{-1}\right)$.

The data indicated that cholesterol levels in Omani camels serum were within normal range and may be used as clinical reference in the breed.

\section{Total bilirubin}

Bilirubins are produced by the breakdown of heme and reduction of biliverdin. It normally circulates in plasma and is taken up by liver cells and conjugated to form bilirubin diglucuronide, the pigment excreted in the bile although some leakage of bilirubin mono- and diglucuronides does occur, but these normally account for less than $5 \%$ of circulating bilirubin. In the bile, more than $80 \%$ is conjugated as the diglucuronide form. Failure of the liver cells to excrete bile, or obstruction of the bile ducts can cause an increased amount of bilirubin in the body fluids and lead to obstructive jaundice.

The mean value of total bilirubin in Omani racing camels was $0.34 \pm 0.124 \mathrm{mg} \cdot \mathrm{dL}^{-1}(5.8 \mu \mathrm{mol} / \mathrm{l})$ with a 
range of $0.10-0.60 \mathrm{mg} \cdot \mathrm{dL}^{-1}$. These figures are comparable to those of $0.51 \pm 0.30 \mathrm{mg} \cdot \mathrm{dL}^{-1}$ reported by Mohamed and Hussein (1999) in Kuwaiti racing camels. Mohri et al (2008) reported a value of $5.3 \mu \mathrm{mol} / \mathrm{l}$ total bilirubin in serum of Iranian camels which is similar to that recorded in Omani camels in the present study. Therefore, the range of $0.10-0.60 \mathrm{mg} \cdot \mathrm{dL}^{-1}$ should be regarded as a normal reference level of the breed.

\section{Serum enzymes}

Liver serum enzyme tests, also known as liver function tests, are tests carried on blood serum that detect inflammation and damage to the liver as well as liver functioning. Liver enzymes include: Aspartate aminotransferase (AST), Alanine aminotransferase (ALT), Gamma-Glutamyl Transpeptidase (GGT). Liver function tests include ALT, AST, GGT, alkaline phosphatase, PT, INR, albumin, and bilirubin.

\section{Alkaline phosphatase (ALP)}

The mean value of ALP in Omani racing camels was $113.9 \pm 29.75 \mathrm{IU} / \mathrm{l}$ with a range of $50-187$. Seleim et al. (2003) reported a lower value of 19.9 IU/l in Egyptian camels. The mean ALP levels in Saudi camel serum (Osman and Al-Busadah, 2003) was $60 \mathrm{U} / \mathrm{l}$ which was not different from those in cattle $(50 \mathrm{U} / \mathrm{l})$ but much lower than that in ewes $(112.4 \mathrm{U} / \mathrm{l})$.

\section{Aspartate aminotransferase (AST)}

Liver enzyme measurements reflect hepatocyte membrane integrity, hepatocyte or biliary epithelial necrosis, cholestasis, or induction phenomenon rather than liver function tests. Duration and magnitude of transaminase activities measured sequentially can predict disease activity and severity and roughly estimate the number of involved cells. Aminotransferases, AST and ALT are present in high concentrations in liver and several other tissues. AST activity is higher in kidney, heart, and skeletal muscle than liver.

The mean value of AST in Omani racing camels was $88.8 \pm 70.03 \mathrm{IU} / \mathrm{l}$ with a range of $57-374 \mathrm{IU} / \mathrm{l}$. That appears to be higher than AST levels in blood of Saudi camels ranged between 24.1-35.1 IU/l (Al-Busadah, 2007) and the 31.4 IU/l in Egyptian camels (Seleim et al., 2003). Osman and Al-Busadah (2003) reported a mean value of AST in Saudi camels of $164.6 \mathrm{U} / \mathrm{l}$ which was comparable to that in sheep $(141.6 \mathrm{U} / \mathrm{l})$ but much higher than that in cattle $(72.4 \mathrm{U} / \mathrm{l})$. Further studies are needed to determine whether the differences in AST between Omani camels and camels in other parts of the world are genetic or clinical.

\section{Alanine aminotransferase (ALT)}

The ALT activity is highest in liver and it is a bout 10,000fold greater than plasma enzyme activity in healthy animals, it has high diagnostic utility to detect liver lesions.

The mean value of ALT in Omani racing camels was
13.3 $\pm 5.97 \mathrm{IU} / \mathrm{l}$ with a range of 9-37. That appears to be comparable to the range of ALT levels in blood of Saudi camels ranged between 8.0-14.5 IU/l (Al-Busadah, 2007). Seleim et al. (2003) reported a value of $19.9 \mathrm{IU} / \mathrm{l}$ in Egyptian camels. Osman and Al-Busadah (2003) reported a mean value of ALT in Saudi camels of 17.2 U/1 which was comparable to that in sheep $(21.0 \mathrm{U} / \mathrm{l})$ but it was less than that in cattle $(34.0 \mathrm{U} / \mathrm{l})$. this indicate normal and healthy liver functions in Omani racing camels.

\section{Gamma-Glutamyl Transpeptidase (GGT)}

GGT is one of the liver enzymes. It is concentrated in the liver, but also present in the gallbladder, spleen, pancreas, and kidneys. GGT blood levels are usually high when the liver is damaged. This test is often done with other tests that measure liver enzymes if there's a possibility of liver damage.

The mean value of GGT in Omani racing camels was $21.3 \pm 10.18 \mathrm{IU} / \mathrm{l}$ with a range of $13-64$. A wide range of GGT (1-49 IU/l) was reported in female camels raised in France (Faye et al., 1995). Osman and Al-Busadah (2003) reported a mean value of GGT in Saudi camels of 25.6 IU/l which was comparable to that in cattle (29.0 IU/l) but much lower than that in sheep (77.0 IU/l). These data indicated that Omani camels has normal liver functions and figures obtained in the current study may be used as clinical reference.

\section{Lactase dehydrogenase (LD)}

The LD is not organ-specific, therefore its levels should be considered in relation to other enzymes. The mean value of LD in Omani racing camels was $419.9 \pm 160.38$ (IU/L) with a range of 303-971. That appears to be higher than LD levels in blood of Saudi camels ranged between 225-280 IU/L (Al-Busadah, 2007). However, Osman and Al-Busadah (2003) reported a mean value of LD in Saudi camels of $455 \mathrm{IU} / \mathrm{l}$ which was comparable to that in sheep (382.4 IU/l) but much lower than that in cattle (726.8 IU/l). Combined with other values of liver enzymes, bilirubin indicate that Omani racing camels were healthy. These values may bused for clinical reference.

\section{Creatine Kinase (CK)}

Skeletal muscles are the major source of CK in the body and the enzyme is used for diagnosis of muscular abnormalities. The mean value of CK in Omani racing camels was $46.3 \pm 16.2$ (IU/L) with a range of $29-107$. This appears to be higher than CK levels in blood of Saudi camels ranged between 29.1-30.3 IU/L by Al-Busadah (2007) who reported that values in Saudi camels are lower than those reported for other camels in Iraq (Al-Ani et al., 1988). Osman and Al-Busadah (2003) reported an exceptionally high value of CK in Saudi camels (408.6 IU/l) which was much higher than that in sheep (121.6 IU/l) and cattle (119.0 IU/l). Normal values of CK in Omani racing camels indicates healthy animals. This is import- 
ant because racing camels usually has a very rigorous training and competition exercise regime.

\section{Serum mineral contents}

Table 1 gives the means, standard deviation, maximum and minimum values of some minerals in Omani camel serum. Generally the macro mineral with the highest concentration in the Omani camel serum was the $\mathrm{Na}$ and within trace elements Fe and $\mathrm{Zn}$.

\section{Sodium (Na)}

Sodium is an essential mineral for cell and body functions. Its importance is evident in racing camels which exercise and compete rigorously and therefore, are usually subjected to severe stress. Na content in camel serum ranged between 132.3 and 160.5 with a mean $144.5 \pm 5.80 \mathrm{mmol} / \mathrm{L}$. This value was comparable to that of $150-164 \mathrm{mmol} / \mathrm{L}$ in Emirate camels (Ayoub and Saleh, 1998; Wernery et al., 1999) and $100-190 \mathrm{mmol} / \mathrm{L}$ reported for "Majaheem", "Maghateer" and "Awarik" Saudi camels (Busadah, 2007). Similar ranges of values were reported for Saudi (Al-Shami, 2009) and Nigerian (Mohammed et al., 2007). Some studies reported a higher range of 300-390 mmol/L (Hassan et al., 1968 in Sudanese camels). Na values obtained in the current study were equivalent to those reported for Saudi camels by Osman and Al-Busadah (2003). The latter authors reported that $\mathrm{Na}$ levels in camels are higher compared to those in cattle and sheep which were in agreement with previous reports (Abdalla et al., 1988).

$\mathrm{Na}$ values in the current study were slightly lower than those reported for rutting and non-rutting male camels (Zia-Rahman et al., 2007). Na serum levels in the Omani dromedary were comparable to those in the Bactrian camels of $148 \pm 32 \mathrm{mmol} / \mathrm{L}$ reported by Liu (2003) and 129-161 mmol/L reported by Wernery et al. (1999).

\section{Chloride (Cl)}

$\mathrm{Cl}$ is an essential electrolyte found in all body fluids and is responsible for maintaining acid/base balance, transmitting nerve impulses and regulating fluid in and out of cells.

$\mathrm{Cl}$ levels in Omani camels ranged between 105.4 and $127.2 \mathrm{mmol} / \mathrm{L}$ with a mean of $113.0 \pm 4.52 \mathrm{mmol} / \mathrm{L}$. these were comparable to the $114-120 \mathrm{mmol} / \mathrm{L}$ in UAE camels (Wernery et. al., 1999). Higher chloride levels were recorded in Egyptian camels was $301.9 \mathrm{mmol} / \mathrm{l}$ (Seleim et al., 2003).

\section{Potassium (K)}

Potassium is the main intracellular ion for all types of animal cells. It is essential for maintaining fluid and electrolyte balance in the animal body. Animals use sodium and potassium differentially to generate electrical potentials in animal cells, especially in nervous tissue. therefore, potassium deficiency in animals results in various neurological dysfunctions.
Mean K values in Omani camels of $4.23 \pm 0.42 \mathrm{mmol} / \mathrm{L}$ (range of 6.5-8.7 mmol/L) were comparable to those reported for Saudi camels (2.9-6.2 mmol/L by Al-Busadah, 2007; 4.2-6.8 $\mathrm{mmol} / \mathrm{L}$ by Al-Shami, 2009; 4.0 by Osman and Al-Busadah, 2003); UAE (4.2 mmol/L by Ayoub and Saleh, 1998; 3.5-5.5 by Wernery et al., 1999); Sudanese (Omer et al., 2008; McGrane and Kenyon, 1984); Nigerian (Mohamed et al., 2007); Egyptian ( $4.29 \mathrm{mmol} / \mathrm{L}$ by Seleim et al., 2003), and other camels (Higgins and Kock, 1986). Kuwaiti camels had levels of 3.0-4.7 mEq/L ( Mohamed and Hussein, 1999);

There were some reports on differences between camel and other species in levels of serum $\mathrm{K}$ contents. For instance Kamalu et al. (2003) reported that K was higher in cattle serum than in camels. $K$ values in the current study were lower than those reported for rutting and non-rutting male camels (Zia-Rahman et al., 2007). Mohammed et al. (2007) reported that male camels had higher $\mathrm{K}$ levels than females in Nigerian camels. K serum levels in the female Omani dromedary were comparable to those in the female Bactrian camels of $4.23 \pm 0.66$ $\mathrm{mmol} / \mathrm{L}$ (Liu, 2003) and 2-12 Bactrian camels (Wernery et al., 1999).

The $\mathrm{Na} / \mathrm{K}$ mean ratio was 28.1 which were lower than that reported for camels in the UAE (39.5) by Ayoub and Saleh (1998) mainly due to higher levels of $\mathrm{Na}$ in Omani camels compared to the Emirate ones. However, generally $\mathrm{Na}$ and $\mathrm{K}$ levels in Omani racing camels were within normal levels and may be used as clinical reference for the breed.

\section{Calcium (Ca)}

In animals, Ca contributes to bone formation, neutralizes rumen excess acidity, enters into the composition of body fluids such as blood, enters into the composition of secretions such as hormones and milk.

The range of Ca values in Omani camels' serum was $8.7-10.3 \mathrm{mg} \cdot \mathrm{dL}^{-1}$ (mean $9.63 \pm 0.43$ ) which is equivalent to $2.41 \mathrm{mmol} / \mathrm{l}$. These values were comparable to those reported for UAE camels $\left(9.5-11.5 \mathrm{mg} \cdot \mathrm{dL}^{-1}\right)$ and 2.8 $\mathrm{mmol} / \mathrm{l}$ reported for Iranian camels (Mohri et al., 2008). $\mathrm{Ca}$ values in Omani camels were at the lower range compared to Saudi camels $\left(7.6-13.1 \mathrm{mg} \cdot \mathrm{dL}^{-1}\right), \mathrm{Al}-\mathrm{Bu}$ sadah, 2007); UAE camels $(11.3 \mathrm{mmol} / \mathrm{L}$; Ayoub and Saleh, 1998) and temperate camels (11.5 mg.dL $\mathrm{d}^{-1}$, Faye et al., 1995). Nonetheless, extremely lower ranges (1.6$2.8 \mathrm{mmol} / \mathrm{L}$ ) were reported in some studies (Higgins and Kock, 1986; McGrane and Kenyon, 1984; Mohamed et al., 2007). Osman and Al-Busadah (2003) reported values of $9.0 \mathrm{mEq} / \mathrm{l}$ for Saudi camels and Wernery et al. (1999)

There were no differences between $\mathrm{Ca}$ values obtained for female camels in the current study and values reported for non-rutting male camels (Zia-Rahman et al., 2007). Ca serum levels in the female Omani dromedary were higher than those in the female Bactrian camels of $2.26 \pm 0.22 \mathrm{mmol} / \mathrm{L}$ (Liu, 2003) and 2.4-2.7 mg/dL 
reported by Wernery et al. (1999).

\section{Phosphorus (P)}

The phosphorus serves in the number of metabolic functions in the animal body with about $80 \%$ of its body concentration used for maintenance and support of the skeleton co-precipitated with calcium. Phosphorus is also a major constituent of the cells, membranes and body fluids and plays an important role in the energy supply. It also acts as a buffer and is involved in phospholipids and fatty acids transfer, the formation of amino acids and structure of DNA and RNA.

The $\mathrm{P}$ serum levels in Omani camels ranged between 5.0 to $8.5 \mathrm{mg} \cdot \mathrm{dL}^{-1}(3.1 \mathrm{mmol} / \mathrm{l})$ with a mean of $6.56 \pm 0.76$ was comparable to that in Egyptian camels $(6.8 \mathrm{mg} / \mathrm{dL}$; Seleim et al., 2003). At its upper level it was higher than the upper range $\left(3.4-7.7 \mathrm{mg} \cdot \mathrm{dL}^{-1}\right)$ reported for UAE camels (3.5-6.0 mg.dL-1 Kuwaiti (Mohamed and Hussein, 1999) and Saudi camels $\left(3.8 \mathrm{mg} \cdot \mathrm{dL}^{-1}\right)$ reported by Osman and Al-Busadah (2003). The latter author's findings indicated that serum $P$ levels in camels are lower than those of cattle and sheep. There were some reports on differences between camel and other species in levels of serum P contents. For instance Kamalu et al. (2003) reported that P was lower in cattle serum than in camels. Values recorded for $\mathrm{P}$ in the present study were higher than those reported for the Bactrian camel $\left(1.65-2.01 \mathrm{mg} \cdot \mathrm{dL}^{-1}\right)$ by Wernery et al. (1999) in UAE.

\section{Iron (Fe)}

Iron plays an important role in forming complexes with molecular oxygen in hemoglobin and myoglobin which are common oxygen transporting proteins in animals. Iron is found at the active site of many important enzymes dealing with cellular respiration and oxidation and reduction in plants and animals. therefore, iron is important for racing animals because of its role in haemoglobin synthesis in the blood. Fe in Omani racing camels had a wider range $\left(56-158 \mu \mathrm{g} \cdot \mathrm{dL}^{-1}\right)$ but its mean value $\left(107.8 \pm 25.54 \mu \mathrm{g} \cdot \mathrm{dL}^{-1}\right)$ was comparable to the range reported for Kuwaiti racing camels $\left(63-170 \mu \mathrm{g} \cdot \mathrm{dL}^{-1}\right)$ by
Mohamed and Hussein (1999). Wernery et al. (1999) reported a range of $87-135 \mu \mathrm{g} \cdot \mathrm{dL}^{-1}$ in $2-12$ year old racing camels in the UAE. Osman and Al-Busadah (2003) reported a Fe level of $80 \mu \mathrm{g} \cdot \mathrm{dL}^{-1}$ in Saudi camels. Lower values of $\mathrm{Fe}\left(46.2 \mu \mathrm{g} \cdot \mathrm{dL}^{-1}\right)$ were reported in Iranian 5 -year old female camels (Badiei et al., 2006).

There were no differences between values obtained for female camels in the current study and values reported for non-rutting male camels (Zia-Rahman et al., 2007). However, there are some reports that age has an effect on Fe levels in camels. For instance Faye et al. (2008) reported that older camels ( $>8$ years) had highest Fe levels $\left(283 \mu \mathrm{g} \cdot \mathrm{dL}^{-1}\right)$ compared to those of 3-7 years of age. The Omani dromedary camels had apparently higher levels of Fe compared to the Bactrian camel (49$57 \mu \mathrm{g} \cdot \mathrm{dL}^{-1}$ ) as reported by Wernery et al. (1999).

\section{Copper $(\mathrm{Cu})$}

Copper is a trace element essential for proper functioning of organs and metabolic processes in animals. High or low levels of $\mathrm{Cu}$ intake can produce adverse health effects. $\mathrm{Cu}$ deficiency cause ataxia or shallal specially in young animals which is common in Oman.

$\mathrm{Cu}$ levels in Omani camels ranged between 54.0 and $89.0 \mu \mathrm{g} \cdot \mathrm{dL}^{-1}$ (mean $72.5 \pm 8.08 \mu \mathrm{g} \cdot \mathrm{dL}^{-1}$ ). Mohamed (2004) reported a comparable value of $57.6-72.4 \mu \mathrm{g} \cdot \mathrm{dL}^{-1}$ in Sudanese adult camels. Serum $\mathrm{Cu}$ levels could be quite variable as reported in camels raised in temperate regions $\left(7-114 \mu \mathrm{g} \cdot \mathrm{dL}^{-1}\right)$ by Faye et al. (1995). Normal Cu levels in ruminants range is $70-140 \mu \mathrm{g} \cdot \mathrm{dL}^{-1}$ or 11-22 $\mu \mathrm{mol} / \mathrm{L}$ according to Abu Damir et al. (2008) and $70-120 \mu \mathrm{g} \cdot \mathrm{dL}^{-1}(12-19 \mu \mathrm{mol} / \mathrm{l})$ according to Faye et al. (2008). Plasma Cu levels were significantly lower in camels $\left(61 \mu \mathrm{g} \cdot \mathrm{dL}^{-1}\right)$ than cattle $\left(111 \mu \mathrm{g} \cdot \mathrm{dL}^{-1}\right)$ as reported by Bengoumi et al. (1998). Faye et al. (2008) reported that normal serum $\mathrm{Cu}$ levels in ruminants are between 70 and $120 \mu \mathrm{g} \cdot \mathrm{dL}^{-1}$ and camel serum $\mathrm{Cu}$ values are within this range (Faye and Bengoumi, 1994). Consequently, the camels at the bottom of the range in the current study may be regarded as at a risk of being $\mathrm{Cu}$ deficient. $\mathrm{Cu}$ deficiency was observed in Oman in other animals such as goats with reports of ataxia. Copper deficiency in camels

Table 4. Coefficients of determination $\left(R^{2}\right)$ and their significance between some serum biochemistry parameters in Omani racing camels

\begin{tabular}{|c|c|c|c|c|c|c|c|}
\hline & $\mathrm{Fe}$ & $\mathrm{Cu}$ & $\mathrm{Ca}$ & $\mathrm{PO}_{4}$ & $\mathbf{K}$ & $\mathrm{Cl}$ & $\mathrm{Na}$ \\
\hline $\mathrm{Fe}$ & 1 & 0.23 & 0.19 & 0.26 & 0.08 & 0.24 & 0.24 \\
\hline $\mathrm{Cu}$ & 0.23 & 1 & 0.21 & -0.10 & -0.25 & 0.27 & 0.20 \\
\hline $\mathrm{Ca}$ & 0.19 & 0.21 & 1 & 0.17 & $0.59^{* * *}$ & $0.69^{* * * *}$ & $0.80^{* * * * *}$ \\
\hline PO4 & 0.26 & -0.10 & 0.17 & 1 & 0.34 & 0.31 & $0.42^{*}$ \\
\hline K & 0.08 & -0.25 & $0.59^{* * * *}$ & 0.34 & 1 & $0.54^{* * *}$ & $0.56^{* * *}$ \\
\hline CL & 0.24 & 0.27 & $0.69^{* * * *}$ & 0.31 & $0.54^{* * *}$ & 1 & $0.92^{* * * * *}$ \\
\hline $\mathrm{Na}$ & 0.24 & 0.20 & $0.80^{* * * *}$ & $0.43^{*}$ & $0.56^{* * *}$ & $0.92^{* * * * *}$ & 1 \\
\hline
\end{tabular}

*: $p<0.05 ;$ **; $p<0.01$; ***; $p<0.001$ 
was also reported in East Africa (Faye and Bengoumi, 1997) and even lower values of $\mathrm{Cu}\left(20.5 \mu \mathrm{g} \cdot \mathrm{dL}^{-1}\right)$ were reported in Iranian 5-year old female camels (Badiei et al., 2006).

Racing camels in Oman are usually kept in confined enclosures and their diet is strictly monitored. The basic fodder is fresh alfalfa which contains higher levels of $\mathrm{Cu}$ compared to Rhodesgrass hay (4.6 vs. $2.8 \mathrm{ppm}$ ) the other common roughage (Abu Damir et al., 2008). However, alfalfa has higher levels of molybdenum (2.2 vs. $0.6 \mathrm{ppm})$ and $\mathrm{SO}_{4}(4.7 \mathrm{ppm})$. It is well established that excess molybdenum, inorganic sulfate, iron or zinc interferes with copper absorption in ruminants (Abu Damir et al., 2008). As mineral supplementation is not widely used with camels in Oman, care should be taken to supplement these animals for $\mathrm{Cu}$. Cupric oxide needle capsules which are safe and effective compared to mineral blocks (Abu Damir et al., 2008) may be a supplement of choice for $\mathrm{Cu}$.

There were no differences between values obtained for female camels in the current study and values reported for non-rutting male camels (Zia-Rahman et al., 2007). Also no sex effects on $\mathrm{Cu}$ levels were observed by Abdalla et al. (1988) and Bengoumi et al. (1995). However, Faye et al. (2008) reported that females had higher levels of $\mathrm{Cu}$ than males (62 vs. $\left.56.7 \mu \mathrm{g} \cdot \mathrm{dL}^{-1}\right)$. Sex differences in mineral contents in camels may be more related to physiological status effect rather than sex per se.

\section{Correlations between serum mineral values}

A correlation analyses was carried out between various blood parameters and coefficient of determination (R2) was listed in Tables 2, 3 and 5. There was a significant correlation between BUN and creatinine as well as between TP and albumin (Table 2). Therefore, either of these parameters may be used to estimate the other. Relation between TP and protein is obvious as TP equals albumin plus total globulins.

There were also high correlations between AST, ALT, GGT and LD (Table 3). These are liver function enzymes and could be used to estimate one another to reduce cost of analyses.

The macro elements $\mathrm{Na}, \mathrm{Ca}$, and $\mathrm{K}$ had significant correlations. This was similar to reports in Omani racing camels (Eltahir et al., 2010). Although there are not many reports on this aspect, Kuria et al. (2006) reported a significant positive correlation between $\mathrm{Na}$ and $\mathrm{Ca}$ but a negative correlation between $\mathrm{Na}$ and $\mathrm{P}$. On the contrary there were no significant correlations within trace elements but there was a significant correlation between $\mathrm{Cl}$ and $\mathrm{Ca}, \mathrm{K}$ and $\mathrm{Na}$ (Table 4).

From a practical point of view, correlations between certain elements would reduce the cost of analyses for these elements as values of some of them may be estimated from other elements using regression equations.

\section{Conclusions}

Findings of the current study provide baseline values that may be used by clinicians for racing camels in Oman and camels raised under similar conditions. Values recorded for all serum metabolic profiles, enzymes and minerals were within the ranges reported for racing camels in the Gulf region and indicated normal health of these animals. There were some significant correlations between some serum parameters that may be used to estimate their values which will reduce cost by reducing the number of elements to be analysed.

\section{References}

Abdalla, O.M., I.A. Wasfi and F.A. Gadir. 1988. The Arabian race camel normal parameters. 1. Haemogram, enzymes and minerals. Comparative Biochemistry \& Physiology, 90:237-239.

Abu Damir, H, T.A. Abbas, and M. Alhaj Ali. 2008. Copper status in breeding and racing camels (Camelus dromedarius) and response to cupric oxide needle capsules. Tropical Animal Health \& Production, 40: 643-648.

Ahmadi-hamedani, Mahmood, Khosro Ghazvinian, Mohammad Mehdi Darvishi. 2014. Hematological and serum biochemical aspects associated with a camel (Camelus dromedarius) naturally infected by Trypanosoma evansi with severe parasitemia in Semnan, Iran. Asian Pacific Journal of Tropical Biomedicine, $4: 743-745$.

Ahmed, Muna MM, M.E. Awad and M.E.S. Barri. 2003. Some micro mineral profile in the serum of female camels as affected by the physiological state. Pakistan Journal of Biological Sciences 6: 1853-1855.

Al-Ani, F.K., H.A. Husayni and DM Power. 1988. A comprehensive biochemical analysis of the blood of camel (Camelus dromedarius). Comparative Biochemistry \& Physiology B, 89: 35-37.

Al-Busadah, K.A. 2007. Some biochemical and haematological indices in different breeds of camels in Saudi Arabia. Scientific Journal of King Faisal University (Basic and Applied Sciences, 8: 131-142.

Al-Shami, S.A. 2009. Comparative determination of serobiochemical constituents in in-door and free grazing camels. Journal of Animal \& Veterinary Advances, 8: 896-898.

Ayoub, M.A. and A.A. Saleh. 1998. A comparative physiological study between camels and goats during water deprivation. Proceeding of the 3rd Annual Meeting of Animal Production Under Arid Conditions, University of United Arab Emirates, 1:71-87.

Badiei K., K. Mostaghni, M., Pourjafar and A. Parchami. 2006. Serum and tissue trace elements in Iranian 
camels (Camelus dromedarius). Comparative Clinical Pathology, 15:58-61.

Bakker, M., X.B., Chen, , D.J. Kyle, E.R. Orskov and D.A. Bourke. 1996. Urinary and plasma purine derivatives in fed and fasted llamas (Lama glama and L. guanacoe). Comparative Biochemistry \& Physiology, 113B 367-374.

Bengoumi M., B. Faye, K. Le Kasm and J.C. Tressol. 1995. Facterus de variation des indicateurs plasmatiques du statut nutritionnel en oligo-elements chez le dromadaire au Maroc. 1. Valeurs usuelles et variations physiologiques. Revue d'élevage et de médecine vétérinaire des pays tropicaux, 48:271-276.

Bengoumi M., A.K. Essamadi,, J.C. Tressol and B. Faye. 1998. Comparative study of copper and zinc metabolism in cattle and camels. Biological Trace Element Research, 63: 81-94.

Bhatia, J.S. 1986. Special aspects of physiology of digestion in camel. Farm Animals, 1: 15-20.

Elias, E. and R. Yagil. 1984. Hematological and serum biochemical values in lactating camels and their newborns. Refuah veterinarith, 41: 7-13.

FAOSTAT (2015) Food and Agriculture Organization of the United Nation statistics. (http://faostat.fao.org/ site/573/DesktopDefault.aspx?PageID=573\#ancor) accessed December, 2015.

Faye, B. and M. Bengoumi. 1997. Trace-elements status in camels. A review, Biol. Trace Elem. Res., 41: 1-11.

Faye, B. and M. Bengoumi. 1997. Comparative study of trace elements status in camel and cow. Journal of Camel Practice \& Research, 4: 213-215.

Faye, B., M. Ratovonanahary, J.P. Chacornac and P. Soubre. 1995. Metabolic profiles and risks of diseases in camels in temperate conditions. Comparative Biochemistry \& Physiology, 112: 67-73.

Faye, B., Rabiha Seboussi and , M. Askar. 2008. Trace elements and heavy metals status in Arabia camel. In: Impact of pollution on animal products, B. Faye and Y. Sinyavskiy (Editors) Springer Science and Business Media B.V. Dordrecht, Netherlands

Eltahir Y.E., H.M., Ali M.H., Mansour and O. Mahgoub. 2010. Serum mineral contents of the Omani racing Arabian camels (Camelus dromedarius). Journal of Animal \& Veterinary Advances 9: 764-770.

Haroun, E.M. 1996. Normal concentrations of some blood constituents in young Najdi camels (Camelus dromedarius). Comparative Biochemistry \& Physiology, 108A: 618-622.

Hassan, Y.M., H., Hoeller and I.M. Hassan. 1968. Observations on the blood constituents of camels in the $\mathrm{Su}$ dan. Sudan Journal of Veterinary Science \& Animal Husbandry, 9: 464-474.

Higgins, A.J. and R.A., Kock. 1986. A guide to the clin- ical examination, chemical restraint and medication of the camel. In: The Camel in Health and Disease, A.J. Higgins (Editors), pp 21-40. Bailliere Tindall, London, UK.

Kamalu, T.N., G.C., Okpe, and A. Williams. 2003. Mineral contents of extracellular fluids in camel and cattle in North East Sahel region of Nigeria. Nigerian Veterinary Journal, 24: 13-20.

Koudier, S., G. Ateeq and E. Kolb. 1988. Studies on the content of total protein, urea, total fat, cholesterol and bilirubin in blood plasma of camels during the course of a year. Monatscheffe für Veterinarmedizine, 43: 139-142. (Veterinary Bulletin 58: 7385).

Kuria, S.G., R.G. Wahome, M.M. Wanyoike and C.K. Gachuri. 2006. Effect of mineral supplement on plasma mineral concentration of camels (Camelus dromedarius) in Kenya. International Journal of Agricultural Biology, 8: 168-171.

Liu, Z.P. 2003. Studies on the haematology and trace element status of adult Bactrian camels (Camelus bactrianus) in China. Veterinary Research Communications, 27: 397-405.

McGrane, J.J. and S.J. Kenyon. 1984. Laboratory diagnosis manual for field veterinarians in the Sudan. Overseas Development Administration, London.

Mehrotra V. and M.L. Gupta. 1989. Seasonal variation in certain blood constituents in camel. Indian Journal of Animal Science, 59: 1559-1561.

Mohammed A.K., A.K.B. Sackey, L.B. Tekdek and J.O. Gefu. 2007. Serum biochemical values of healthy adult one humped camel (Camelus dromedarius) introduced into sub-Humid climate in Shika-Zaria, Nigeria. Journal of Animal \& Veterinary Advances. 6: 597-600

Mohamed H.E. 2004. The Zink and Copper content of the plasma of Sudanese camels (Camelus dromedarius). Veterinary Research Communications, 28, 359363.

Mohamed H.A. and A.N. Hussein. 1999. Studies on normal haematological and serum biochemical values of the 'Hijin' racing camels (Camelus dromedarius) in Kuwait. Veterinary Research Communications, 23: 241-248.

Mohri M., H.R. Moosavian and M.J. Hadian. 2008. Plasma biochemistry of one-humped camel (Camelus dromedarius): Effects of anticoagulants and comparison with serum. Research in Veterinary Science, 85: 554-558.

OMAF (Oman Ministry of Agriculture \& Fisheries). 2012. Results of the Agricultural Census 2012. Department of Statistics and Information, Directorate General of Planning and Investments Promotion, Ministry of Agriculture and Fisheries, Sultanate of Oman. (http://maf.gov.om/Pages/PageCreator.aspx- 
?lang $=\mathrm{EN} \& \mathrm{I}=0 \& \mathrm{CId}=0 \& \mathrm{CMSId}=800631 \& \mathrm{DId}=0$ ) accessed October 26th 2015.

Omer, S.A., H. Agab, H.A. Samad Gussey and I.Y. Turki. 2008. Effect of feed type on some blood constituents of Sudanese growing camel (Camelus dromedarius) calves. Sudan Journal of Veterinary Medicine \& Animal Husbandry, 47: 107-116.

Osman T.E.A. and K.A. Al-Busadah. 2003. Normal concentrations of twenty serum biochemical parameters of she-camels, cows and ewes in Saudi Arabia. Pakistan Journal of Biological Sciences, 6:1253-1256.

Roussel, J.D., T.J. Aranas and S.H. Seyby. 1982. Metabolic profile testing in Holstein cattle in Louisiana. American Journal of Veterinary Research, 43: 1658-1660.

Saeed, A. and M.M. Hussein. 2008. Change in normal haematological values of camels (Camelus dromedarius): influence of age and sex. Comparative Clinical Pathology, 17: 263-266.

SAS Institute Inc. 2000. SAS for Windows, Version 6.0, ed. SAS Users Guide: Statistics, Version 5.18. ed. SAS Institute Inc., Cary, NC, pp. 1-956.

Schalm, O.W., N.C. Jain and W.J. Carrol. 1975. Veterinary Haematology (3rd Edition) Lea and Febiger, Philadelphia, USA pp 807.

Seleim, R.S., Amal R. Tos, Sahar R. Mohamed, H.S. Nada and R.A. Gobran. 2003. ELISA and other tests in the diagnosis of Pasterella multocida in camels. http:// www.priory.com/vet/camel.htm (accessed November 2015).

Wernery, U., M.E. Fowler, R. Wernery. 1999. Color Atlas of Camelid Hematology. Blackwell, Wissenschaft-Verlag Berlin, Wien.

Yadav, S.B. and U.K. Bissa. 1998. Factors affecting some blood constituents in camels - A review. Proceedings of the Third Annual Meeting for Animal Production under Arid Conditions, Vol. 2: 32-48. United Arab Emirates University, Al-Ain, United Arab Emirates.

Zia-ur-Rahman, N., Shazia Anwer Bukhari Ahmed, , N. Akhtar and I.U. Haq. 2007. Serum hormonal, electrolytes and trace elements profiles in the rutting and non-rutting one-humped male camel (Camelus dromedarius). Animal Reproduction Science, 101: 172-178. 